\title{
MAL62 overexpression enhances uridine diphosphoglucose-dependent trehalose synthesis and glycerol metabolism for cryoprotection of baker's yeast in lean dough
}

\author{
Xi Sun ${ }^{1,2^{*}}$, Jun Zhang ${ }^{1,2}$, Zhi-Hua Fan ${ }^{1,2}$, Ping Xiao ${ }^{1,2}$, Feng Li3 ${ }^{3,4}$, Hai-Qing Liu ${ }^{1,2}$ and Wen-Bi Zhu ${ }^{5}$
}

\begin{abstract}
Background: In Saccharomyces cerevisiae, alpha-glucosidase (maltase) is a key enzyme in maltose metabolism. In addition, the overexpression of the alpha-glucosidase-encoding gene MAL62 has been shown to increase the freezing tolerance of yeast in lean dough. However, its cryoprotection mechanism is still not clear.

Results: RNA sequencing (RNA-seq) revealed that MAL62 overexpression increased uridine diphosphoglucose (UDPG)-dependent trehalose synthesis. The changes in transcript abundance were confirmed by quantitative reverse transcription-polymerase chain reaction (qRT-PCR) and enzyme activity assays. When the UDPG-dependent trehalose synthase activity was abolished, MAL62 overexpression failed to promote the synthesis of intracellular trehalose. Moreover, in strains lacking trehalose synthesis, the cell viability in the late phase of prefermentation freezing coupled with MAL62 overexpression was slightly reduced, which can be explained by the increase in the intracellular glycerol concentration. This result was consistent with the elevated transcription of glycerol synthesis pathway members.

Conclusions: The increased freezing tolerance by MAL62 overexpression is mainly achieved by the increased trehalose content via the UDPG-dependent pathway, and glycerol also plays an important role. These findings shed new light on the mechanism of yeast response to freezing in lean bread dough and can help to improve industrial yeast strains.
\end{abstract}

Keywords: Saccharomyces cerevisiae, Trehalose synthesis pathway, Alpha-glucosidase, Maltose, Glycerol, Freezing tolerant, RNA-seq, Lean dough

\section{Background}

The use of frozen dough is now gradually emerging in a multitude of bakery and food chains due to its less time-consuming production after freezing and cheaper bake-off stations [1, 2]. However, freezing often causes

\footnotetext{
*Correspondence: sunxi@tjau.edu.cn

${ }^{1}$ College of Biological Engineering, Tianjin Agricultural University, Tianjin 300384, People's Republic of China

Full list of author information is available at the end of the article
}

oxidative stress and cell death to baker's yeast [3], which reduces the yeast growth and gas production capacity $[4$, 5]. A number of protective molecules have been identified in yeast stress tolerance [6-8]. Among them, the disaccharide trehalose, which protects the cell membrane and stabilizes the protein structure, has captured wide attention [9]. Yeast trehalose is regulated by two major biosynthetic systems, system I and II. System I is uridine-5'-diphosphoglucose (UDPG) dependent and contains several protein complexes, including

c) The Author(s) 2020. This article is licensed under a Creative Commons Attribution 4.0 International License, which permits use, sharing, adaptation, distribution and reproduction in any medium or format, as long as you give appropriate credit to the original author(s) and the source, provide a link to the Creative Commons licence, and indicate if changes were made. The images or other third party material in this article are included in the article's Creative Commons licence, unless indicated otherwise in a credit line to the material. If material is not included in the article's Creative Commons licence and your intended use is not permitted by statutory regulation or exceeds the permitted use, you will need to obtain permission directly from the copyright holder. To view a copy of this licence, visit http://creativeco mmons.org/licenses/by/4.0/. The Creative Commons Public Domain Dedication waiver (http://creativecommons.org/publicdomain/ zero/1.0/) applies to the data made available in this article, unless otherwise stated in a credit line to the data. 
one trehalose-6-phosphate synthase (encoded by TPS1) [10], one trehalose-6-phosphate phosphatase (encoded by TPS2), and one trehalose-synthesis protein complex (encoded by TSL1) [11]. The system II trehalose synthetic pathway is adenosine-diphosphoglucose (ADPG) dependent and uses maltose, a disaccharide, to synthesize trehalose $[12,13]$.

In baker's yeast, the $M A L$ gene family, which regulates maltose metabolism, consists of five multigene complexes, including MAL1, MAL2, MAL3, MAL4, and $M A L 6$. Each gene complex encodes a maltose permease, an alpha-glucosidase, and a transacting MAL-activator [14]. We have shown previously that overexpression of MAL62 enhances the cryotolerance of baker's yeast [15] and speculated that multiple pathways may be involved in this phenomenon [16]. However, the mechanism for the enhanced freezing tolerance is still unknown.

To better understand the role of MAL62 overexpression in the freezing tolerance of baker's yeast in lean dough, and its possible mechanism, we used transcriptome analysis to characterize a MAL62-overexpressing strain and investigated the effects of overexpression of MAL62 and deletion of the TPS1 gene on maltose metabolism, trehalose and glycerol accumulation, and the freezing tolerance of baker's yeast in lean dough.

\section{Materials and methods}

\section{Strains, plasmids, and growth conditions}

The yeast and bacterial strains as well as the plasmids used in this study are listed in Table 1 . The parent industrial strain BY14 was used to create the high-leavening haploid BY14a strain, which was used to create all of the other strains, including the overexpression and deletion strains.
The Escherichia coli DH5a and yeast strains were cultured as described previously [15]. Briefly, yeast cells in yeast extract peptone dextrose (YPD) medium ( $1 \%$ yeast extract, $2 \%$ peptone, and $2 \%$ dextrose) were cultured at $30{ }^{\circ} \mathrm{C}$ on a rotor with a speed of $180 \mathrm{rpm}$. G418 (final concentration of $0.08 \%$ ) (Thermo Fisher, Waltham, MA, USA) was added to YPD plates to select G418-resistant transformants. After growing in YPD for $24 \mathrm{~h}$, cultured cells $(20 \mathrm{~mL})$ were inoculated into $200 \mathrm{~mL}$ of cane molasses medium $\left(0.5 \%\right.$ yeast extract, $0.05 \%\left(\mathrm{NH}_{4}\right)_{2} \mathrm{SO}_{4}$, and $12^{\circ}$ Brix cane molasses), giving an initial $\mathrm{OD}_{600}$ value of 0.4 . The cells were cultured at $30^{\circ} \mathrm{C}$ to an $\mathrm{OD}_{600}$ value of 1.8 (about $24 \mathrm{~h}$ ), then centrifuged at $4{ }^{\circ} \mathrm{C}$ and $5000 \mathrm{rpm}$ for $5 \mathrm{~min}$, and finally washed twice with sterile water. A modified low sugar model liquid dough (LSMLD) medium [17] was mainly used for the measurements of trehalose, intracellular glycerol, and the cell viability during prefermentation and after prefermentation freezing.

\section{RNA sequencing (RNA-seq)}

RNA-seq-based transcriptome analysis was performed to identify the differentially expressed genes after MAL62 overexpression. Cells constitutively overexpressing MAL62 (B + MAL62) and the control (BY14a + K) were grown in cane molasses medium. RNA isolation and cDNA synthesis were performed as previously described [18]. Briefly, total RNA was isolated using the hot acid phenol method, followed by DNase treatment. The RNA concentration was measured using a Qubit fluorometer and a Qubit RNA Assay Kit (Thermo Fisher Scientific, Waltham, MA, USA). The RNA integrity was assessed using a Bioanalyzer 2100 system (Agilent Technologies, Santa Clara, CA, USA) and an RNA Nano 6000 Assay Kit.

Table 1 Characteristics of the strains used in the present study

\begin{tabular}{|c|c|c|}
\hline Strains or plasmids & Relevant characteristics & Reference or source \\
\hline \multicolumn{3}{|l|}{ Strains } \\
\hline E. coli DH5a & 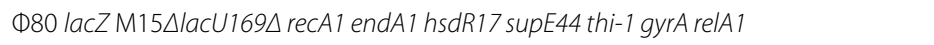 & YCC \\
\hline $\mathrm{BY} 14 \mathrm{a}^{\mathrm{a}}$ & MATa & YCC \\
\hline$B Y 14 a+K$ & MATa, Yep-K & [15] \\
\hline$B+M A L 62$ & MATa, Yep-PMK & {$[15]$} \\
\hline B-T & MATa, tpsi $1::$ KanMX & This study \\
\hline$B-T+M$ & MATa, tps $1 \triangle \because:$ MAL62 & This study \\
\hline$B+$ TPS1 & MATa, Yep-PTK & [16] \\
\hline \multicolumn{3}{|l|}{ Plasmids } \\
\hline pUG6 & $\begin{array}{l}\text { E. coli/S. cerevisiae shuttle vector, containing Amp }{ }^{+} \text {, loxP-kanMX-loxP disruption cas- } \\
\text { sette }\end{array}$ & [31] \\
\hline PPGK1 & bla LEU2 PGK1 $-P G K 1_{T}$ & [58] \\
\hline
\end{tabular}

YCC: Yeast Collection Center of the Tianjin Key Laboratory of Industrial Microbiology

a BY14a was selected as a high-leavening capacity haploid from 32 clones derived from BY14 (data not shown) 
The RNA-seq libraries were generated from $1 \mu \mathrm{g}$ of RNA from each sample using a NEBNext Ultra RNA Library Prep Kit (New England Biolabs, Ipswich, MA, USA), according to the manufacturer's instructions. The clustering of samples, which was index coded to attribute individual sample sequences, was performed using a cBot Cluster Generation System (Illumina, San Diego, CA, USA). The RNA libraries were sequenced using an Illumina Hiseq 2500 system (Illumina). Paired-end reads of $125 \mathrm{bp} / 150 \mathrm{bp}$ were generated and analyzed.

\section{RNA-seq data analysis}

The differential expression of two different groups was analyzed using DESeq R software (https://www.bioco nductor.org, version 1.18.0). Genes with a false-discovery rate-adjusted $p$-value $<0.05$ were considered as differentially expressed.

Volcano plots and hierarchical clustering were used to screen the differentially expressed genes and to analyze the clusters of differentially expressed genes. GOseq [19] was used for gene ontology (GO) term enrichment analysis. The Kyoto Encyclopedia of Genes and Genomes (KEGG) was used to determine the pathways with upregulated genes. STRING (https://www.string-db.org/) and Cytoscape (https://cytoscape.org) software programs were used for protein-protein interaction (PPI) network analysis.

\section{Validation of gene expression levels}

Quantitative reverse transcription-polymerase chain reaction (qRT-PCR) was used to detect the expression levels of the target genes. qRT-PCR was conducted using the THUNDERBIRD probe one-step qRT-PCR kit (TOYOBO, Osaka, Japan). The yeast UBC6 gene, which encodes a ubiquitin-conjugating enzyme involved in endoplasmic reticulum-resident proteins for degradation, was used as a reference gene [20]. The PCR primers are listed in Table 2. Yeast cDNA was extracted using an RNAiso kit (Takara Biotech, Dalian, China) and a PrimeScript RT reagent kit with gDNA eraser (Perfect Real Time, Takara Biotech). The PCR was conducted using a CFX96 real-time PCR system (Bio-Rad, Hercules, CA, USA). The reaction conditions were as follows: $95{ }^{\circ} \mathrm{C}$ for $30 \mathrm{~s} ; 61^{\circ} \mathrm{C}$ for $20 \mathrm{~min} ; 95^{\circ} \mathrm{C}$ for $30 \mathrm{~s} ; 43$ cycles of $95^{\circ} \mathrm{C}$ for $5 \mathrm{~s}, 55^{\circ} \mathrm{C}$ for $10 \mathrm{~s}$, and $74{ }^{\circ} \mathrm{C}$ for $15 \mathrm{~s}$; and $72{ }^{\circ} \mathrm{C}$ for $5 \mathrm{~min}$. Quantitative analysis of the qRT-PCR was conducted using the $2^{-\Delta \Delta C T}$ method.

\section{Measurement of enzymatic activities}

Cells were grown in cane molasses medium to the late-log phase, and the Tps1 activity was measured as previously described [21]. One unit of Tps1 activity was defined as the production of $1.0 \mu \mathrm{M}$ of trehalose-6-phosphate per minute. The final activity was calculated based on the cell dry weight (CDW). Data were expressed as the mean \pm standard deviation (SD) from three independent experiments.

For $\alpha$-glucosidase activity determination, cells were grown in cane molasses medium to an $\mathrm{OD}_{600}$ value of 1.8 , then inoculated into LSMLD medium, and cultivated for $2.5 \mathrm{~h}$. Crude extracts were prepared using the Salema-Oom method [22], and the $\alpha$-glucosidase activity was measured as previously described [23]. Data were expressed as the mean \pm SD from three independent experiments.

To determine the activity of other enzymes, including hexokinase, phophoglucomutase, UGPase, and glycerol3-phosphate dehydrogenase (G3PDH), cells were grown in cane molasses medium to the late-log phase, centrifuged at $5000 \mathrm{rpm}$ and $4{ }^{\circ} \mathrm{C}$ for $5 \mathrm{~min}$, and then washed twice with cold sterile water. The activities of hexokinase [24], phosphoglucomutase [25], UGPase [26], and G3PDH [27] were assayed as described previously. The protein concentration was measured using the Bio-Rad protein assay kit (Bio-Rad, Richmond, USA), according to the manufacturer's instructions. Data were expressed as the mean $\pm \mathrm{SD}$ from three independent experiments.

\section{Measurement of intracellular trehalose contents}

Cells were grown in cane molasses medium to the latelog phase for the trehalose accumulation experiments. For the trehalose degradation tests during prefermentation, cells were grown in LSMLD medium for $25 \mathrm{~min}$. Freshly cultured cells $(0.1 \mathrm{~g})$ were washed twice with water. Trehalose was extracted with $4 \mathrm{~mL}$ of $0.5 \mathrm{M}$ trichloroacetic acid. Trehalose in the extract was estimated by the method outlined by Stewart [28] as well as with the anthrone reagent described by Spiro [29]. Data were expressed as the mean \pm SD from three independent experiments.

\section{Measurement of extracellular maltose}

For the measurement of extracellular maltose, cells were grown in LSMLD medium for $4 \mathrm{~h}$. Cultured cells were filtered through a $0.45-\mu \mathrm{m}$-pore-size cellulose acetate filter (Millipore, Danvers, MA, USA). The extracellular maltose was measured by high-pressure liquid chromatography (HPLC) analysis using an Aminex HPX-87H column (Bio-Rad, Hercules, CA, USA) and an HPLC pump (Waters 515). The column was eluted at $65^{\circ} \mathrm{C}$ with $5 \mathrm{mM} \mathrm{H}_{2} \mathrm{SO}_{4}$ at a flow rate of $0.6 \mathrm{~mL} / \mathrm{min}$ [30]. Maltose was detected with a differential refractometer detector (Waters $410 \mathrm{RI}$ ). Data were expressed as the mean $\pm \mathrm{SD}$ from three independent experiments. 
Table 2 Primers used in this study

\begin{tabular}{|c|c|}
\hline Name & $5^{\prime} \rightarrow 3^{\prime}$ DNA sequences \\
\hline \multicolumn{2}{|c|}{ For recombinant construction } \\
\hline TU1-F & GATGCTGTTGTTCTTTCTTCTGTTT \\
\hline TU1-R & CCTGCAGCGTACGAAGCTTCAGCTGAGTTCTATGTCTTAATAAGTCTGTA \\
\hline KAN1-F & TACAGACTTATTAAGACATAGAACTCAGCTGAAGCTTCGTACGCTGCAGG \\
\hline KAN1-R & GATCGTCTCATTTGCATCGGGTTCAGCATAGGCCACTAGTGGATCTGATA \\
\hline TD1-F & TATCAGATCCACTAGTGGCCTATGCTGAACCCGATGCAAATGAGACGATC \\
\hline TD1-R & ACTTTCTAAAATGGCTATATAGGGG \\
\hline TU2-R & TTCAGTTTTGGATAGATCAGTTAGAAGTTCTATGTCTTAATAAGTCTGTA \\
\hline PGKP-F & TACAGACTTATTAAGACATAGAACTTCTAACTGATCTATCCAAAACTGAA \\
\hline PGKP-R & TTTCTGGATGATCAGAAATAGTCATGTTTTATATTTGTTGTAAAAAGTAG \\
\hline MAL-F & СTACTTTTTACAACAAATATAAAACATGACTATTTCTGATCATCCAGAAA \\
\hline MAL-R & AGAAAAGAAAAAAATTGATCTATCGTTATTTGACGAGGTAGATTCTACCT \\
\hline PGKT-F & AGGTAGAATCTACCTCGTCAAATAACGATAGATCAATTTTTTTCTTTTCT \\
\hline PGKT-R & CCTGCAGCGTACGAAGCTTCAGCTGTAACGAACGCAGAATTTTCGAGTTA \\
\hline KAN2-F & TAACTCGAAAATTCTGCGTTCGTTACAGCTGAAGCTTCGTACGCTGCAGG \\
\hline \multicolumn{2}{|c|}{ For PCR verification } \\
\hline UUK-F & ATCTAAGAGGACGGTTGCTG \\
\hline UUK-R & GTCAAGACTGTCAAGGAGGG \\
\hline KDD1-F & TCGCAGACCGATACCAGGAT \\
\hline KDD1-R & TCAACGGATGGGAAAGCAAT \\
\hline UUP-F & GCGGTCCGTTCTGTGGTT \\
\hline UUP-R & СCCTCTGTGGCGGTCTAT \\
\hline PPM-F & CACATGCTATGATGCCCACT \\
\hline PPM-R & CGCAAACAAACGGAGGTA \\
\hline MPT-F & CGAAAGATAAGCCCAATG \\
\hline MPT-R & CTGTAACGAACGCAGAAT \\
\hline PTK-F & AAATTCTGCGTTCGTTAC \\
\hline PTK-R & CCGTCAGCCAGTTTAGTC \\
\hline KDD2-F & TATGTGAATGCTGGTCGCTAT \\
\hline KDD2-R & CCGTTGCTACTGCCGTTA \\
\hline \multicolumn{2}{|l|}{ For RT-qPCR } \\
\hline qGDB1-F & AGCCTAACTTCGGCACTC \\
\hline qGDB1-R & CACCGTCATCTAATCTCAAATA \\
\hline qEMI2-F & GGCAAGGATGTCGTGAGGTT \\
\hline qEMI2-R & AGCCTGAAGTGTAGCAGTGG \\
\hline qGLK1-F & ATCACGAAGTTGCCACAG \\
\hline qGLK1-R & TCACCCAAGAACATCCCT \\
\hline $\mathrm{qH} \times \mathrm{K} 2-\mathrm{F}$ & TCCGTTTACAACAGATACCC \\
\hline $\mathrm{qHXK2-R}$ & ATAACAGCGGCACCAGCA \\
\hline qHXK1-F & GTGTCAAGACCACTCTGCCA \\
\hline qHXK1-R & GGATCTTTGCTTGCGTCACC \\
\hline qPGM2-F & GAAAAGGACGGTGTTTGGGC \\
\hline qPGM2-R & GGCTGGGAAGGCGGAATTAA \\
\hline qPRM15-F & TAAGCAAGACCGCAACCCAA \\
\hline qPRM15-R & CCAATCCCTGAGACGCTTGT \\
\hline qUGP1-F & CGAGAGCAACACAAACAGCG \\
\hline qUGP1-R & CCGGGTTGGGAGACTTGATC \\
\hline qTPS1-F & GGGGCAAGGTTGTTCTG \\
\hline qTPS1-R & TCACGGGTGGACGAGAC \\
\hline
\end{tabular}


Table 2 (continued)

\begin{tabular}{ll}
\hline Name & $\mathbf{5}^{\prime} \rightarrow \mathbf{3}^{\prime} \mathbf{D}$ NA sequences \\
\hline qTPS2-F & CCACCACTGCCCAAGACAAT \\
qTPS2-R & CAGGTTGCGTTCGGTCTTG \\
qTPS3-F & TGCTCCGTCTGCTAGAGTCT \\
qTPS3-R & GGATCGACATCTGGAACGCT \\
qUBC6-F [59] & GGACCTGCGGATACTCCTTAC \\
qUBC6-R [59] & TAATCGTGTGTTGGGCTTGA \\
\hline
\end{tabular}

\section{Yeast strain construction}

Yeast genomic DNA was extracted using a yeast DNA isolation kit (Omega Bio-Tek, Norcross, GA, USA). The tps1 1 (B-T) strain (Table 1) was constructed as follows: the TPS1U fragment containing the TPS1 upstream homologue sequence and the TPS1D fragment containing the TPS1 downstream homologue sequence were amplified from the BY14a yeast genome with the primers TU1-F/TU1-R and TD1-F/TD1-R, respectively. The fragment $\operatorname{Kan} M X$ was amplified from the plasmid pUG6 using the primers KAN1-F/KAN1-R [31]. Then, the fragments of TPS1U, TPS1D, and loxP-KanMX-loxP were transferred into BY14a using the lithium acetate/polyethylene glycol method [25]. G418 (300 $\mu \mathrm{g} / \mathrm{mL})$ was used to select the positive recombinants, which were further verified by PCR with the primers UUK-F/UUK-R and KDD1-F/KDD1-R. The tps1A plus MAL62-overexpression $(\mathrm{B}-\mathrm{T}+\mathrm{M})$ strain (Table 1 ) was constructed as follows: The MAL62 gene was amplified from the BY14a genome with the primers TU1-F/TU2-R, TD1-F/TD1$\mathrm{R}$, and MAL-F/MAL-R. The fragments containing the yeast phosphoglycerate kinase gene promoter (PGK1p) and terminator (PGK1t) were amplified from the BY14a genome with the primers PGKP-F/PGKP-R and PGKTF/PGKT-R, respectively. The fragment loxP-KanMX-loxP was amplified from the plasmid pUG6 using the primer pair KAN2-F/KAN1-R. Six fragments (TPS1U, $P G K 1_{P}$, $M A L 62, P G K 1_{T}, K a n M X$, and TPS1D) were transferred into the BY14a strain, and the recombinant $\mathrm{B}-\mathrm{T}+\mathrm{M}$ strain was verified via $P C R$ using the primer pairs of UUP-F/UUP-R, PPM-F/PPM-R, MPT-F/MPT-R, PTK-F/ PTK-R, and KDD2-F/KDD2-R. B + MAL62, the MAL62overexpression strain, was constructed as described previously [15].

\section{Measurement of intracellular glycerol content}

To measure the intracellular glycerol levels, cells were cultured in cane molasses medium for $24 \mathrm{~h}$ at $30^{\circ} \mathrm{C}$ and then transferred to LSMLD medium. The cells were prefermented for $5,10,15,20$, and $25 \mathrm{~min}$. Approximately $25 \mathrm{mg}$ (wet weight) of cells was washed, resuspended in $1 \mathrm{~mL}$ of deionized water, and boiled twice (30 min, with occasional shaking). The supernatants were then centrifuged for $10 \mathrm{~min}$ at $15,000 \times g$. The level of glycerol was measured as described previously [32]. Data were expressed as the mean \pm SD from three independent measurements.

\section{Measurement of cell viability and leavening ability}

Yeast cells were cultured in cane molasses medium [5 g/L yeast extract, $0.5 \mathrm{~g} / \mathrm{L}\left(\mathrm{NH}_{4}\right)_{2} \mathrm{SO}_{4}$, and $12^{\circ}$ Brix cane molasses] for $24 \mathrm{~h}$ at $30{ }^{\circ} \mathrm{C}$ and then transferred to LSMLD medium. The cells were prefermented for 5,10 , 15,20 , and $25 \mathrm{~min}$, and then moved to a $-20{ }^{\circ} \mathrm{C}$ freezer for 7 days. The cell viability was measured after freezing, as described previously [15]. Data were expressed as the mean \pm SD from three independent experiments.

The leavening abilities were measured by the amount of carbon dioxide $\left(\mathrm{CO}_{2}\right)$ produced by the lean dough. The lean dough contained $280 \mathrm{~g}$ of standard flour, $4 \mathrm{~g}$ of salt, $9 \mathrm{~g}$ of fresh yeast, and $150 \mathrm{~mL}$ of water. The dough was mixed at $30{ }^{\circ} \mathrm{C}$ for $5 \mathrm{~min}$ and divided into 50 -g pieces. The dough pieces were placed in a fermentograph (Type JM 451; Mekab Försäljnings AB, Nässjö, Sweden). The production of $\mathrm{CO}_{2}$ was measured at $30{ }^{\circ} \mathrm{C}$ for $2 \mathrm{~h}$. To examine the effect of freezing and thawing on the leavening ability, the dough was frozen for 1 to 4 weeks at -20 ${ }^{\circ} \mathrm{C}$ and then thawed for $30 \mathrm{~min}$ at $30{ }^{\circ} \mathrm{C}$. The production of $\mathrm{CO}_{2}$ was measured while the dough was at $30{ }^{\circ} \mathrm{C}$ for $2 \mathrm{~h}$. The measurement was repeated three times, and data were expressed as the mean $\pm \mathrm{SD}$.

\section{Statistical analysis}

Data were represented as the mean $\pm S D$ from three independent experiments. Differences among the various strains were analyzed using analysis of variance. Differences between the parent and the MAL62-overexpression strains were analyzed using the Student's $t$-test. For all analyses, $p<0.05$ was considered statistically significant.

\section{Results}

MAL62 overexpression enhances the UDPG-dependent trehalose synthesis

RNA-seq analysis was performed to identify the differentially expression genes when MAL62 was overexpressed. 
The results showed that MAL62 overexpression caused significant changes in gene expression (Fig. 1a). Compared to the control (BY14a+K), 1460 genes were downregulated (Fig. 1b, green) and 1506 genes were upregulated (Fig. 1b, red). KEGG analysis revealed that the upregulated genes were mainly enriched in the metabolism and synthesis of carbohydrates (Fig. 1c). GO analysis of the biological processes (molecular function, cellular component, and biological process) showed that several processes involving trehalose were affected by MAL62 overexpression (Fig. 1d). In addition, STRING analysis demonstrated that MAL62 overexpression caused upregulation of TPS1, TPS2, TPS3, and UGP1, which are all key genes of the UDPG pathway (Fig. 2 and Additional file 1: Figure S1).

To further examine the possible involvement of the UDPG pathway on trehalose synthesis, the expression levels of trehalose metabolism-related genes (GLK1, EMI2, HXK1, HXK2, PGM2, PRM15, UGP1, GDB1, TPS1, TPS2, and TPS3) were analyzed by qRT-PCR. Our results showed that all of these genes, except for TPS2, had a significantly higher expression in the B+MAL62

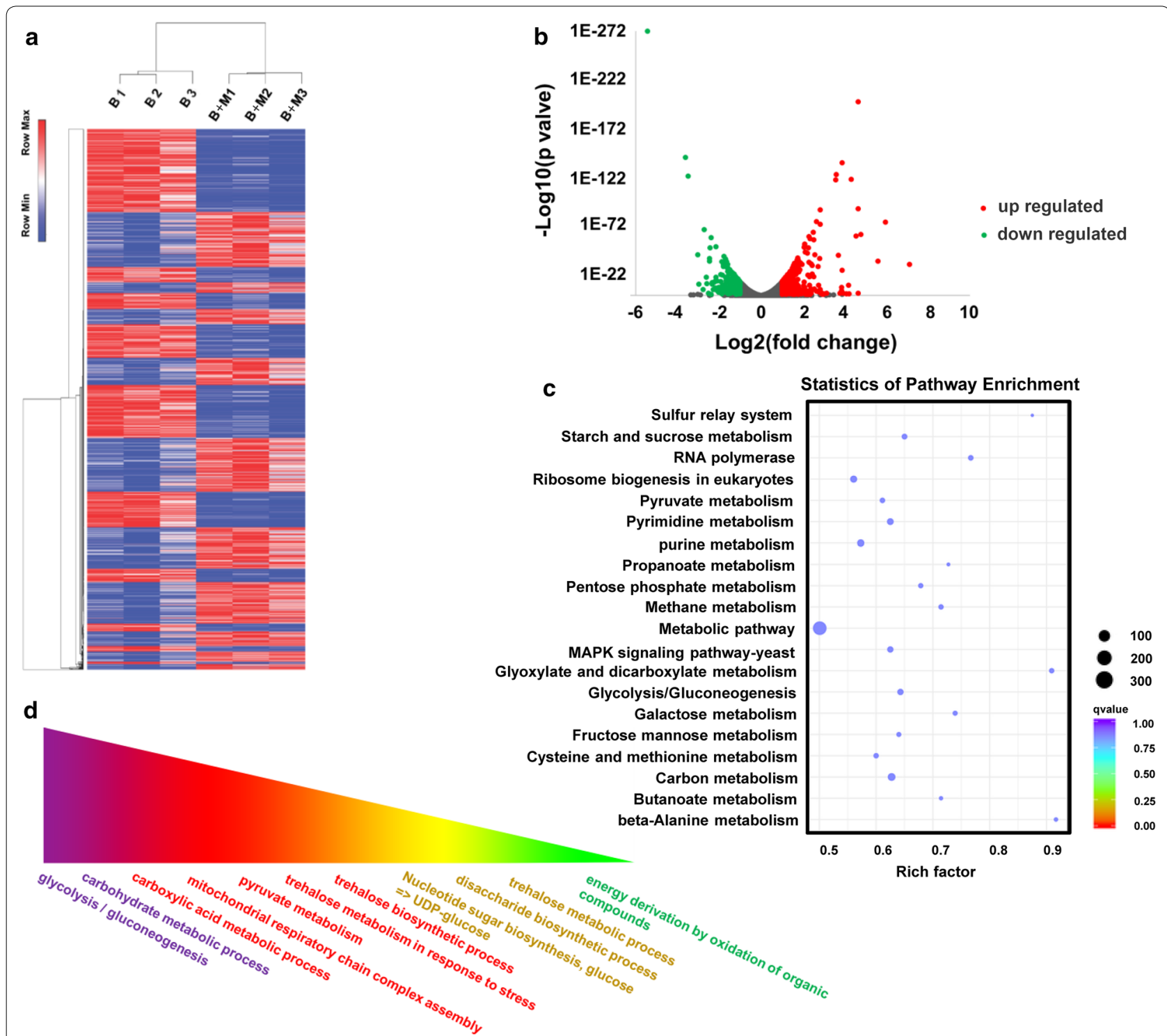

Fig. 1 Results of RNA-Seq transcriptome analysis. a Hierarchical clustering of the significant genes (B indicates BY14a + K, B + M indicates $B+$ MAL62). $\mathbf{b}$ Volcano plot of all genes. The downregulated genes are shown in green, and the upregulated genes are shown in red. $\mathbf{c}$ Kyoto Encyclopedia of Genes and Genomes analyses. $\mathbf{d}$ Gene ontology functional enrichment analyses. The functions are arranged from deep to shallow according to their relevance 


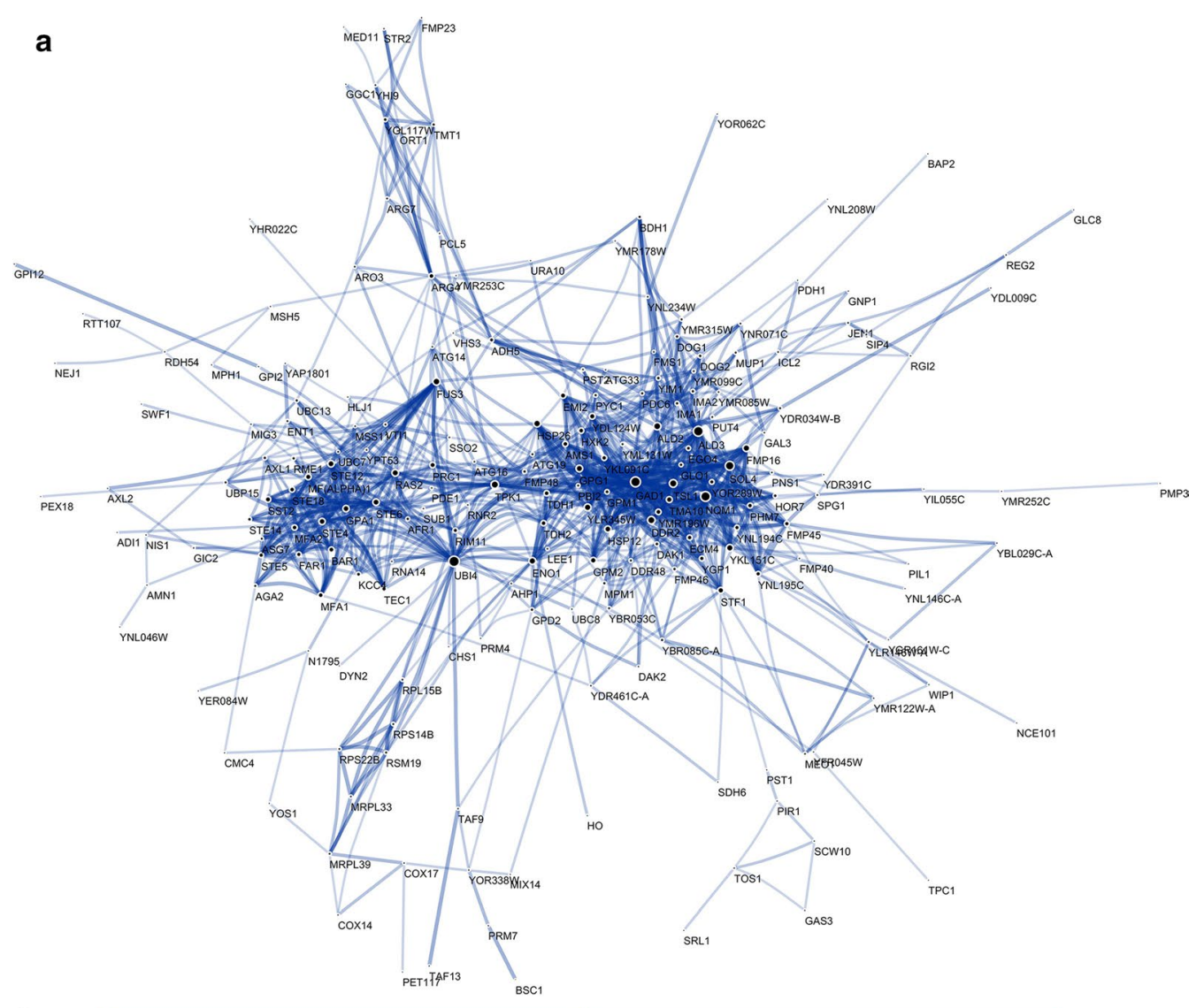

b

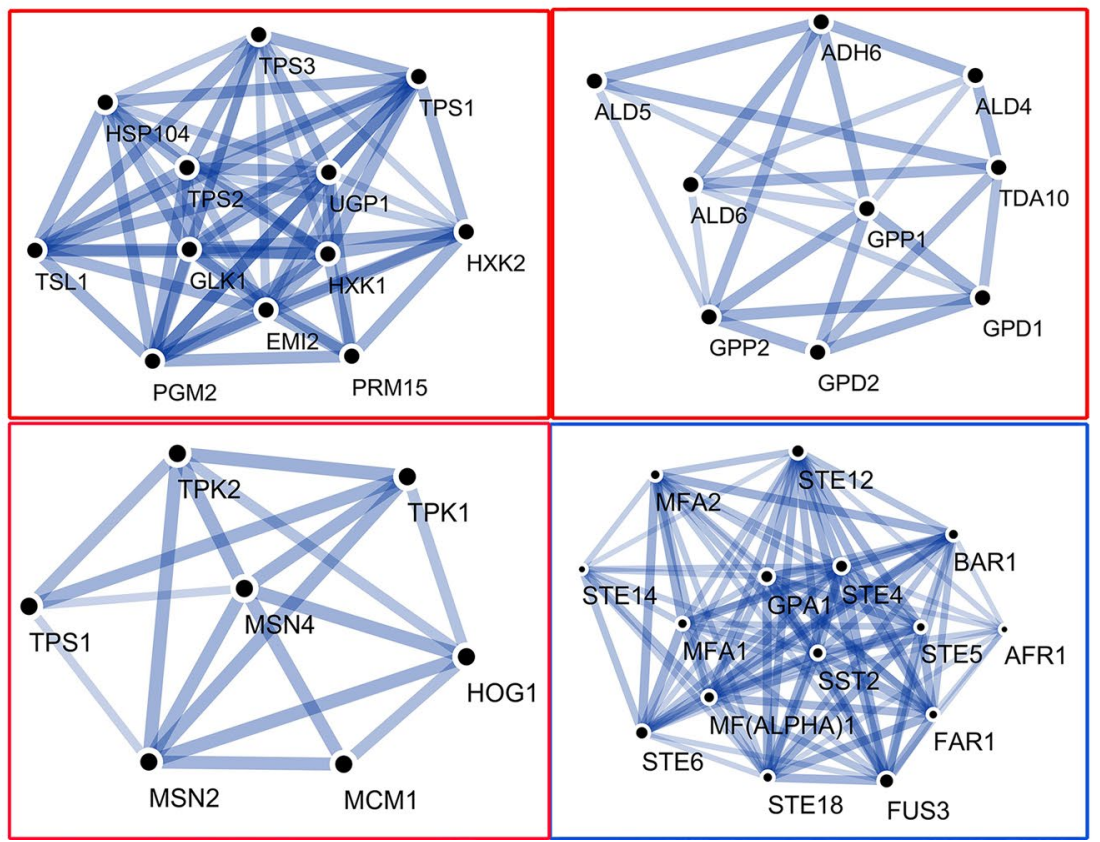

Fig. 2 Interactions between the upregulated proteins. a Protein-protein interaction networks. b Significant modules in the protein-protein interaction network 
strain than in the BY14a $+\mathrm{K}$ strain (Fig. 3a). The fold changes were as follows: GDB1, 2.36; TPS1, 2.27; UGP1, 1.90; HXK1, 1.89; EMI2, 1.66; PRM15, 1.69; HXK2, 1.75; PGM2, 1.86; GLK1, 1.41; and TPS3, 1.47. No significant change of TPS2 was observed between the B + MAL62 and BY14a $+\mathrm{K}$ strains. The enzyme activity measurements showed that all of the tested key enzymes related to the UDPG pathway, except for hexokinase, were of higher activity in the B+MAL62 strain than in the BY14a + K strain (Table 3).

Disruption of the TPS1 gene diminishes the UDPGdependent trehalose synthase activity [13]. To further understand the role of MAL62 overexpression in trehalose synthesis, we constructed a tps $1 \Delta$ strain $(\mathrm{B}-\mathrm{T})$, and MAL62 was overexpressed in a tps $1 \Delta$ strain $(\mathrm{B}-\mathrm{T}+\mathrm{M})$ to eliminate the effects of the UDPG-dependent trehalose synthesis pathway. Figure $3 \mathrm{~b}$ shows that the expression levels of TPS1 in the B-T and B-T $+\mathrm{M}$ strains were not detectable. Compared with the maltose fermentation (a maltose concentration decrease of 39.86\%) and alphaglucosidase activity (3.91 $\mathrm{mmol} \mathrm{mg}^{-1} \mathrm{~min}^{-1}$, on average) of $\mathrm{B}+\mathrm{MAL} 62, \mathrm{~B}-\mathrm{T}$ and $\mathrm{B}-\mathrm{T}+\mathrm{M}$ had lower consumption of maltose (a maltose concentration decrease of only $6.07 \%$, on average) and lower activities of alpha-glucosidase (just maintained at $1.46 \mathrm{mmol} \mathrm{mg} \mathrm{min}^{-1}$, on average) in the first $60 \mathrm{~min}$ of fermentation (Fig. 4). One possible cause of this is the slower growth rates of the two tps1 $1 \Delta$ strains [33]. However, it is worth noting that even when the alpha-glucosidase activities started to rise at $60 \mathrm{~min}$ and reached the peak at nearly $150 \mathrm{~min}$ during fermentation, the trehalose levels in the B-T and B-T $+M$ strains were still not detectable These results suggest that MAL62 overexpression activates the UDPG pathway,
Table 3 Activity of enzymes related to the UDPG pathway and glycerol metabolism

\begin{tabular}{lcc}
\hline & BY14a + K & B+ MAL62 \\
\hline Hexokinase (U/mg pro) & $1.19 \pm 0.09$ & $1.30 \pm 0.11$ \\
Phosphoglucomutase (U/mg pro) & $0.14 \pm 0.01$ & $0.31 \pm 0.03^{*}$ \\
UGPase (U/mg pro) & $0.43 \pm 0.06$ & $1.10 \pm 0.08^{*}$ \\
Tps1 (U/g CDW) & $0.79 \pm 0.07$ & $1.20 \pm 0.05^{*}$ \\
Glycerol-3-phosphate dehydrogenase & $1.5 \pm 0.07$ & $2.83 \pm 0.21^{*}$ \\
$\quad$ (U/mg pro) & & \\
\hline
\end{tabular}

Data are expressed as the mean \pm SD from three independent experiments CDW cell dry weight

${ }^{*} \mathrm{P}<0.05$ in comparison with the parent strain

which then causes the accumulation of intracellular trehalose and enhanced cryotolerance. To further confirm this finding, we overexpressed TPS1 (B+TPS1). The consumption of maltose and the activity of alpha-glucosidase of B + TPS1 were similar to those of BY14a and B-T (Fig. 4). However, the trehalose accumulation (Fig. 4b, c) and cell viability (Fig. $5 \mathrm{~b}$ ) remained at the same level as those of B + MAL62, further suggesting that TPS1 plays an important role in cryoprotection.

\section{MAL62 overexpression enhances glycerol metabolism}

RNA-seq and STRING analyses showed that MAL62 overexpression caused upregulation of GPD1, GPD 2, GPP1, and GPP2 (Fig. 2, Additional file 2: Figure S2, and, Additional file 3: Figure S3). GPD1 and GPD 2 encode the rate-limiting enzymes in the high-osmolarity glycerol mitogen-activated protein kinase (HOG-MAPK) pathway, which induces glycerol accumulation [3437]. We assayed the activity of glycerol-3-phosphate
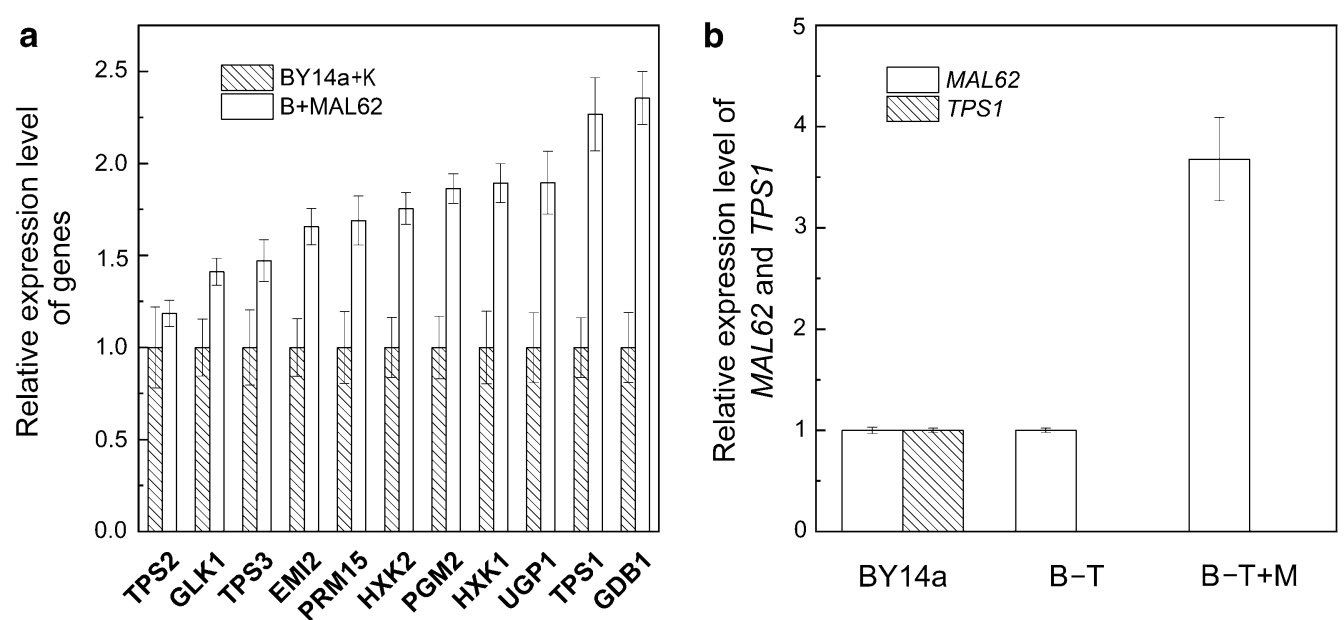

Fig. 3 Quantitative RT-PCR analysis of the relative expression levels of genes in the recombinant strain B+MAL62 and the control strain BY14a $+K$ (a) as well as in the recombinant strains B-T and B-T $+M$ and the control strain BY14a (b). Data are expressed as the mean \pm SD (indicated as error bars) of three independent experiments 

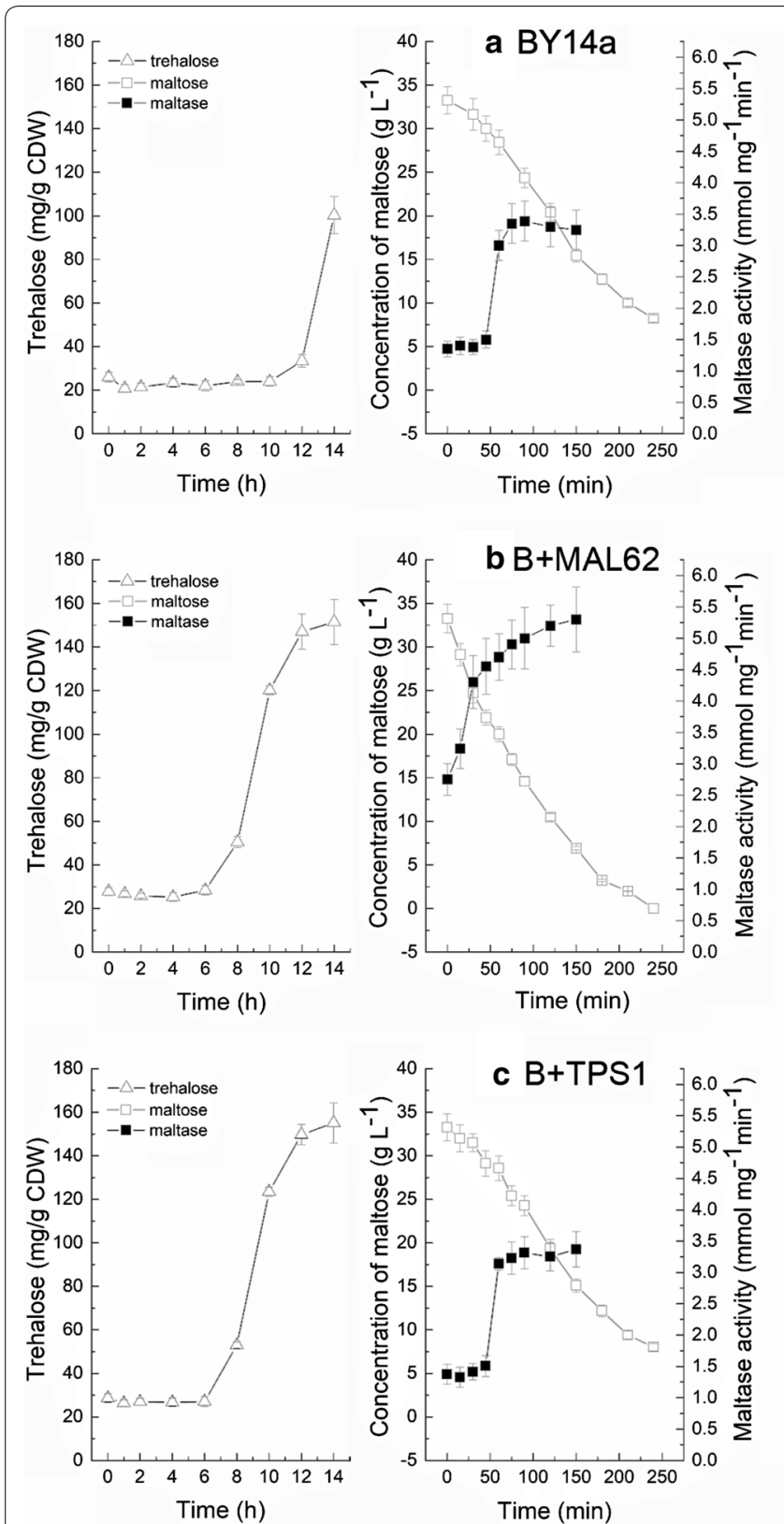
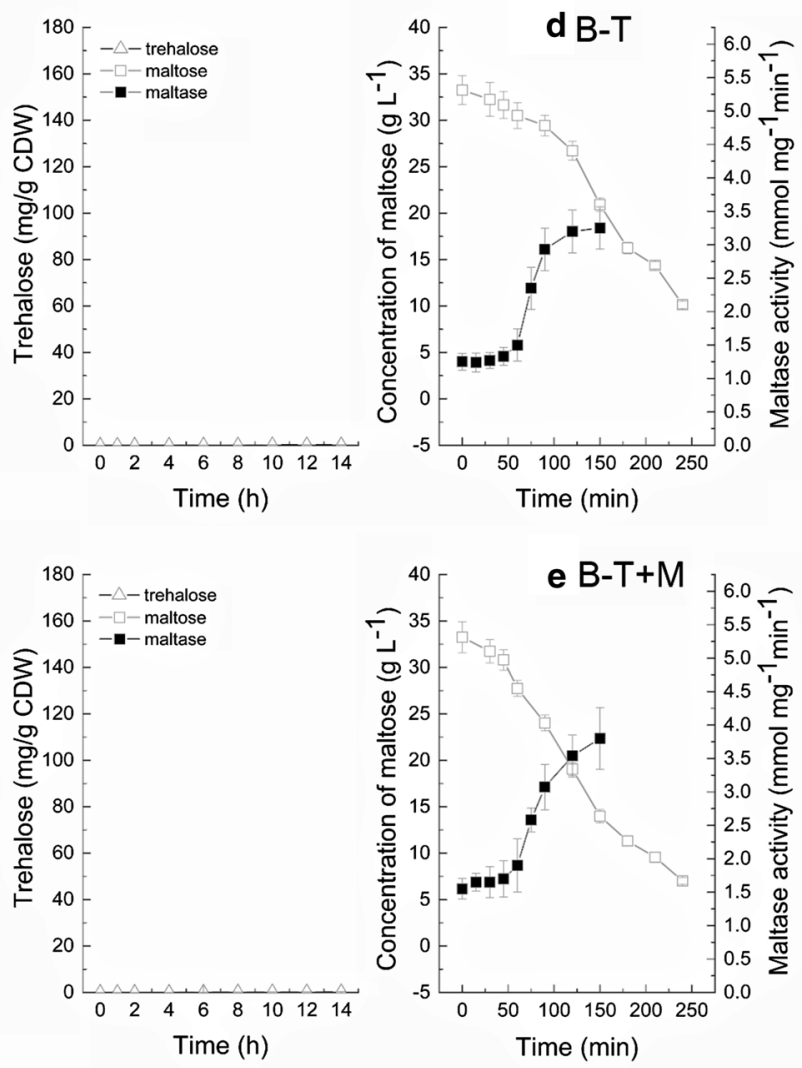

Fig. 4 Measurements of alpha-glucosidase (maltase) activity, residual maltose concentration, and intracellular trehalose content in five yeast strains: BY14a (a), B + MAL62 (b), B +TPS1 (c), B-T (d), and B-T + M (e)

dehydrogenase in the BY14a $+\mathrm{K}$ and B + MAL62 strains. As shown in Table 3, the activity of glycerol-3-phosphate dehydrogenase in B + MAL62 was $88.7 \%$ higher than that in $\mathrm{BY} 14 \mathrm{a}+\mathrm{K}$, suggesting that MAL62 overexpression causes an increase in the glycerol content.

To further determine the change of glycerol content and its possible cryopreservation effect in the MAL62overexpressed strain, we used $\mathrm{B}-\mathrm{T}$ and $\mathrm{B}-\mathrm{T}+\mathrm{M}$ to eliminate the effects of trehalose. As shown in Fig. 5a, the B-T strain exhibited a similar intracellular glycerol synthesis rate compared to the BY14a strain, suggesting that the deletion of TPS1 did not affect glycerol synthesis. However, the intracellular glycerol content in the $B-T+M$ strain was significantly higher than that in the BY14a or B-T strain after prefermentation for $15 \mathrm{~min}$ and freezing for 7 days $(p<0.05)$. After prefermentation for $25 \mathrm{~min}$ and freezing for 7 days, the intracellular glycerol content in the $\mathrm{B}-\mathrm{T}+\mathrm{M}$ strain 

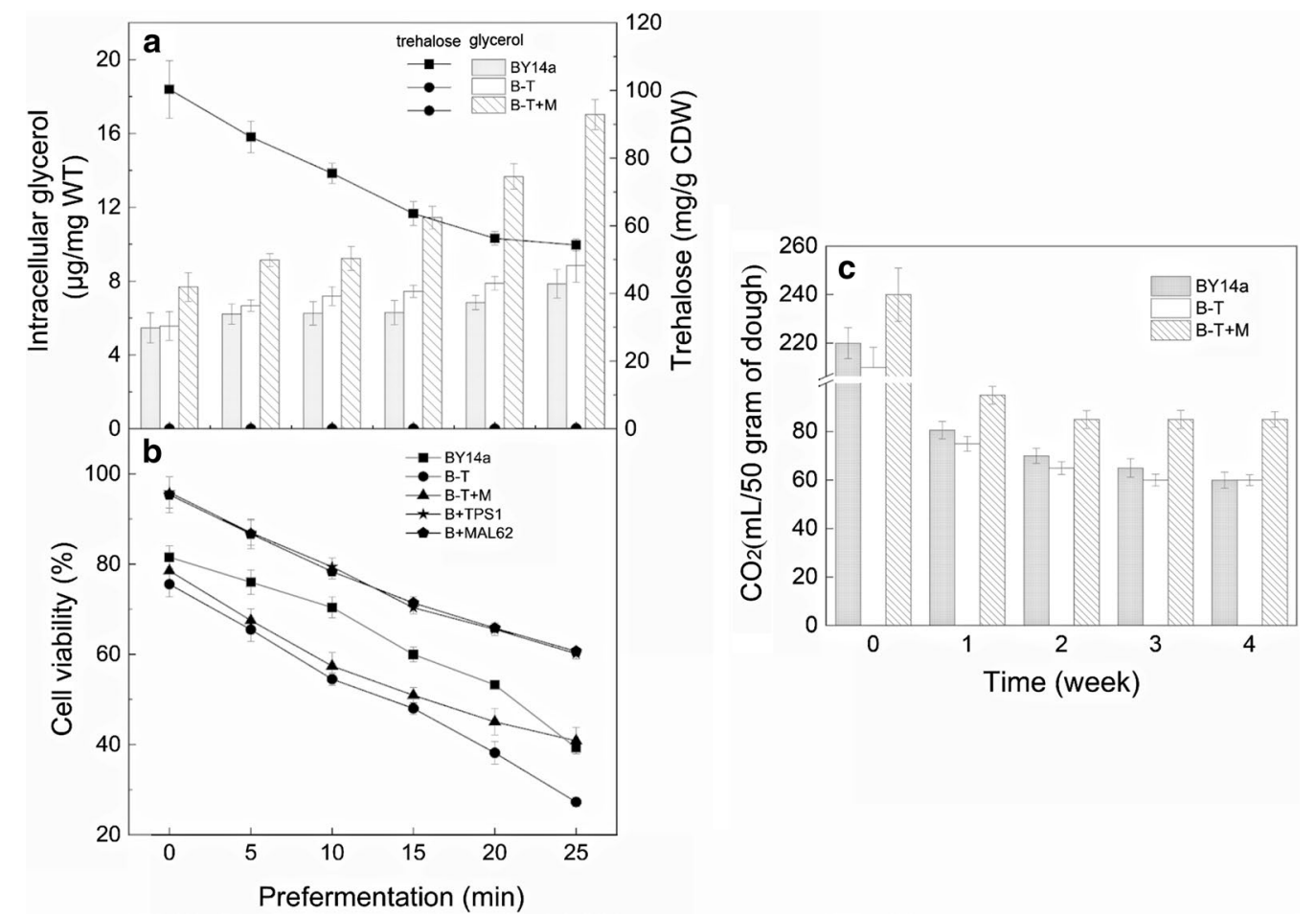

Fig. 5 Contents of intracellular glycerol and trehalose (a) and cell viability (b) after different fermentation times (0-25 min) and freezing in LSMLD medium for 7 days. Measurement of yeast $\mathrm{CO}_{2}$ production in the lean dough after different periods of freezing (0-4 weeks) (c). Data are expressed as the mean $\pm S D$ (indicated as error bars) of three independent experiments

increased by approximately $121.5 \%$, compared with prefermentation for $0 \mathrm{~min}$, while the intracellular glycerol contents in the BY14a and B-T strains increased by only $23.9 \%$ and $32.8 \%$, respectively. These results suggest that MAL62 overexpression positively correlates with the accumulation of intracellular glycerol.

Next, we examined whether the increased glycerol level by MAL62 overexpression affects the freezing tolerance by measuring the cell viability. As shown in Fig. 5b, a longer prefermentation duration caused a significant decrease in the cell viability after freezing for 7 days in all three strains (BY14a, B-T, and $B-T+M)$. After prefermentation for $25 \mathrm{~min}$, the cell viability of the BY14a and B-T $+M$ strains was similar, but the cell viability of the B-T strain was significantly lower than those of the BY14a and B-T $+M$ strains $(p<0.05)$. Compared to the BY14a and B-T strains, the cell viability of the $B-T+M$ strain showed a minor decrease after prefermentation for 15 min (Fig. 5b). These findings suggest that in addition to triggering the accumulation of trehalose, MAL62 overexpression also causes an increment in the glycerol content, which can enhance freezing tolerance.
Increased glycerol content by MAL62 overexpression enhanced the leavening ability after long-term freezing The possible effect of the increased glycerol level by MAL62 overexpression on the leavening ability after long-term freezing was determined by measuring $\mathrm{CO}_{2}$ production. As shown in Fig. 5c, the $\mathrm{CO}_{2}$ production in all strains decreased as the freezing time increased from 1 to 4 weeks. However, the $\mathrm{CO}_{2}$ production of the $\mathrm{B}-\mathrm{T}+\mathrm{M}$ strain was significantly higher than either the BY14a or $\mathrm{B}-\mathrm{T}$ strain before freezing $($ time $=0)$ and after freezing for 1 to 4 weeks $(p<0.05)$. These results suggest that the increased glycerol content by MAL62 overexpression can mitigate the loss of the leavening ability after exposure to the stress induced by long-term freezing.

\section{Discussion}

Our comparative transcriptome analysis revealed that overexpression of MAL62 causes significant differences in gene expression, as compared to its wild-type control $(B Y 14 a+K)$. Many of these genes are involved in the stress response, especially freezing stress pathways. Several genes involved in starch and sucrose metabolism, glycerophospholipid metabolism, and glycerolipid 
metabolism are also differentially expressed between these two strains. KEGG analysis further confirmed that many of the pathways are involved in cryotolerance of the B + MAL62 strain. In baker's yeast, trehalose is believed to be the primary compound affecting the viability of yeast in frozen dough $[38,39]$. Using mutants of $S$. cerevisiae deficient in trehalose synthesis, degradation, or transport, studies have shown that trehalose can protect cells exposed to freezing and dehydration [40-42]. We have previously reported that the enhanced freezing tolerance by MAL62 overexpression is related to the increased activity of Tps1 [16]. Our current study provides further evidence that genes involved in starch and sucrose metabolism, including GLK1, EMI2, HXK1, HXK2, PGM2, PRM15, and UGP1, had a higher expression level in the B+MAL62 strain (Fig. 3a and Additional file 1: Figure S1). In addition, PPI network analysis revealed a high score for Tps1, Tps2, and Tps3 (Fig. 2b). The enzyme activities, metabolism of trehalose and glycerol, cell viability, and gas production after freezing provided further confidence (Table 3 and Figs. 4, 5a, b) that the enhanced freezing tolerance by MAL62 overexpression is related to the UDPG-dependent trehalose synthesis pathway. However, MAL62 is an enzyme, not a transcription factor. It is not clear how its overexpression affects the expression of so many genes. One possibility is that MAL62 may affect the expression of some transcription factors due to the fact that the MAL6 locus has been reported to be located in nuclei $[43,44]$.

Microorganisms often accumulate different solutes, such as ions, amino acids, and polyols, to mitigate water loss $[45,46]$ when they face a water shortage. Baker's yeast responds to freeze stress-induced hyperosmotic stress by activating the HOG-MAPK pathway, which induces glycerol accumulation [34-37]. It has been extensively documented that glycerol 3-phosphate dehydrogenase, which is encoded by GPD1 and GPD2, is the key enzyme in the production of glycerol $[47,48]$. The strong upregulation of GPD1 under hyperosmotic stress [49, $50]$ is at least partly controlled by the HOG1-MAPK cascade $[49,51]$. Our transcriptome analysis revealed that HOG1, Msn2, and Msn4 scored high on the PPI network (Fig. 2b). Genes and rate-limiting enzyme activity (glycerol-3-phosphate dehydrogenase) involved in glycerol biosynthesis were also upregulated in the B+MAL62 strain (Additional file 2: Figure S2 and Additional file 3: Figure S3, and Table 3), suggesting that MAL62 overexpression induces the accumulation of glycerol through the HOG pathway.

It has been reported that stress-responsive elements (STRE) mediate transcriptional regulation of the trehalose synthase genes TPS1, TPS2, and TPS3 as well as the glycerol 3-phosphate dehydrogenase genes GPD1 and GPD2 [52, 53]. Msn2 and Msn4, which bind specifically to STRE-containing oligonucleotides [54], are controlled by the HOG-MAPK pathway [55]. Hence, we speculated that the accumulation of trehalose and glycerol by MAL62 overexpression may start with the activation of the HOG-MAPK pathway, after which the trehalose synthase genes and glycerol 3-phosphate dehydrogenase genes are upregulated through STRE-mediated transcriptional regulation. This may explain our previous speculation that the enhancement in freezing tolerance by MAL62 overexpression may involve multiple pathways [16]. A possible relationship between maltose metabolism and cryoprotectant synthesis is illustrated in Fig. 6.

Compared with the $\mathrm{B}-\mathrm{T}$ and $\mathrm{B}-\mathrm{T}+\mathrm{M}$ strains, the BY14a strain has a higher intracellular trehalose content, which results in a higher cell viability at the onset of prefermentation (Fig. 5a, b). The B-T strain, which lacks trehalose, had a lower cell viability in the beginning, and the viability decreased rapidly. The B-T $+M$ strain, which had a higher glycerol level, showed a smaller decrease in cell viability in the later stage of prefermentation (Fig. 5a, b). This phenomenon suggests that the high glycerol content induced by MAL62 overexpression has some positive effects on the freezing tolerance. Due to the fact that trehalose and glycerol are the primary compounds affecting the freezing tolerance [38], the differences in trehalose and glycerol accumulation may play an important role in the different cell viabilities exhibited by the three strains after prefermentation and freezing for 7 days. It is possible that the increased level of glycerol and other gene expression changes caused by MAL62 overexpression may play a role in the enhanced cell viability and leavening ability. Studies are underway in our laboratory to further confirm the roles of glycerol and other related genes in yeast cryoprotection.

Hyperosmotic stress, which causes desiccation and electrolyte release from yeast cells, is a major factor for loss of leavening activity after freezing and thawing [39]. Besides, the formation of ice crystals during freezing causes damage to the cell membrane and subcellular structure [56]. Previous studies have reported that fermentation with high glycerol-producing strains can result in improved cell viability and gas retention in dough [57]. Consistent with the report, our results showed that the B-T $+\mathrm{M}$ strain exhibits a higher glycerol content as well as improved gas retention in the dough, especially after the storage of the frozen dough for more than 1 week. We believe that this is partially because the HOG pathway and glycerol synthesis were activated by MAL62 overexpression. It is worth noting that the $\mathrm{B}-\mathrm{T}+\mathrm{M}$ strain showed a high level of $\mathrm{CO}_{2}$ production during the 4 weeks of frozen dough storage. A 


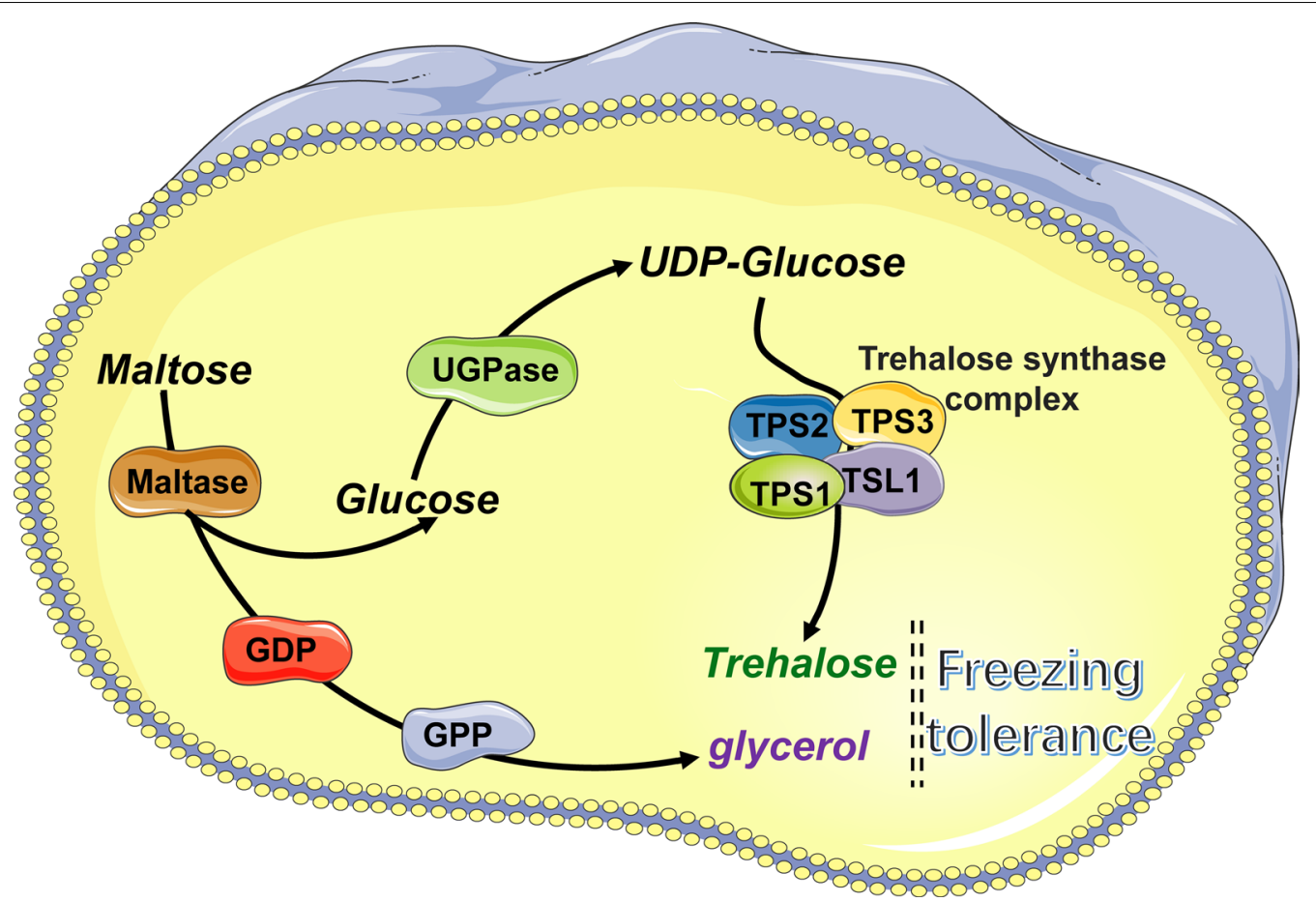

Fig. 6 Proposed regulatory mechanism of MAL62 overexpression in yeast. MAL62 overexpression induces the UDPG-dependent trehalose synthesis pathway and the HOG-MAPK-dependent glycerol synthesis pathway

possible reason is that MAL62 overexpression enhances maltose metabolism, which is vital for dough fermentation [15].

\section{Conclusion}

This study indicates that MAL62 overexpression induces cryoprotection by the increased level of trehalose via the UDPG-dependent trehalose synthesis pathway. The increased glycerol content by MAL62 overexpression also plays an important role in the cryoprotection, especially in the later stage of prefermentation. We believe that these findings shed new light on the mechanism of yeast response to freezing in lean bread dough and can help to improve industrial yeast strains.

\section{Supplementary information}

Supplementary information accompanies this paper at https://doi. org/10.1186/s12934-020-01454-6.

Additional file 1: Figure S1. The starch and sucrose metabolism pathway was significantly increased.

Additional file 2: Figure S2. The glycerolipid metabolism pathway was significantly increased.

Additional file 3: Figure S3. The glycerophospholipid metabolism pathway was significantly increased.

\section{Acknowledgements}

This work was supported by the National Natural Science Foundation of China (31701569) and the Tianjin Municipal Special Program of Talents Development for Excellent Youth Scholars (TJTZJH-QNBJRC-1-19).

\section{Authors' contributions}

XS conceived the study, carried out the experiments, and drafted the manuscript. PX and FL participated in the strain construction. JZ, ZHF, HQL, and WBZ assisted in the fermentation experiments. All authors read and approved the final manuscript.

\section{Competing interests}

The authors declare that they have no competing interests.

\section{Author details}

${ }^{1}$ College of Biological Engineering, Tianjin Agricultural University, Tianjin 300384, People's Republic of China. ${ }^{2}$ Tianjin Engineering Research Center of Agricultural Products Processing, Tianjin 300384, People's Republic of China. ${ }^{3}$ Frontier Science Center for Synthetic Biology and Key Laboratory of Systems Bioengineering (Ministry of Education), Tianjin University, Tianjin 300072, People's Republic of China. ${ }^{4}$ Collaborative Innovation Center of Chemical Science and Engineering (Tianjin), School of Chemical Engineering and Technology, Tianjin University, Tianjin 300072, People's Republic of China. ${ }^{5}$ Experiments and Teaching Center for Agricultural Analysis, Tianjin Agricultural University, Tianjin 300384, People's Republic of China.

Received: 2 July 2020 Accepted: 9 October 2020

Published online: 19 October 2020 


\section{References}

1. Gaikwad S, Arya SS. Influence of frozen storage on quality of multigrain dough, par baked and ready to eat thalipeeth with additives. Lwt-Food Sci Technol. 2018;96:350-6.

2. Panadero J, Randez-Gil F, Prieto JA. Heterologous expression of type I antifreeze peptide GS-5 in baker's yeast increases freeze tolerance and provides enhanced gas production in frozen dough. J Agric Food Chem. 2005a;53:9966-70.

3. Liu M, Liang Y, Zhang H, Wu G, Wang L, Qian H, Qi X. Production of a recombinant carrot antifreeze protein by Pichia pastoris GS115 and its cryoprotective effects on frozen dough properties and bread quality. Lwt-Food Sci Technol. 2018;96:543-50.

4. Jia C, Huang W, Tang X, Ding S, Yang W, Li Z, Fu G, Rayas-Duarte P. Antifreeze activity of gamma-polyglutamic acid and its impact on freezing resistance of yeast and frozen sweet dough. Cereal Chem. 2016;93:306-13.

5. Zhang $\mathrm{C}$, Zhang $\mathrm{H}$, Wang $\mathrm{L}$, Yao $\mathrm{H}$. Validation of antifreeze properties of glutathione based on its thermodynamic characteristics and protection of baker's yeast during cryopreservation. J Agric Food Chem. 2007:55:4698-703.

6. Sasano Y, Haitani Y, Hashida K, Ohtsu I, Shima J, Takagi H. Enhancement of the proline and nitric oxide synthetic pathway improves fermentation ability under multiple baking-associated stress conditions in industrial baker's yeast. Microb Cell Fact. 2012;11:40.

7. Teixeira MC, Godinho CP, Cabrito TR, Mira NP, Sa-Correia I. Increased expression of the yeast multidrug resistance $A B C$ transporter Pdr18 leads to increased ethanol tolerance and ethanol production in high gravity alcoholic fermentation. Microb Cell Fact. 2012;11:98.

8. Liu H-L, Chang J-J, Thia C, Lin Y-J, Lo S-C, Huang C-C, Li W-H. Characterizing an engineered carotenoid-producing yeast as an anti-stress chassis for building cell factories. Microb Cell Fact. 2019:18:155.

9. Eleutherio E, Panek A, De Mesquita JF, Trevisol E, Magalhães R. Revisiting yeast trehalose metabolism. Curr Genet. 2015;61:263-74.

10. Liu Y, Han L, Qin L, Zhao D. Saccharomyces cerevisiae gene TPS1 improves drought tolerance in Zea mays $L$ by increasing the expression of SDD1 and reducing stomatal density. Plant Cell Tissue Organ Culture. 2015;120:779-89.

11. Luzhetskyi T, Semkiv M, Dmytruk K, Sibirny AA. Improving of stress response and high temperature fermentation efficiency in yeast Saccharomyces cerevisiae. Yeast. 2015;32:S158-S158.

12. Paschoalin VM, Costa-Carvalho VL, Panek AD. Further evidence for the alternative pathway of trehalose synthesis linked to maltose utilization in Saccharomyces. Curr Genet. 1986;10:725-31.

13. Ferreira JC, Thevelein JM, Hohmann S, Paschoalin VM, Trugo LC, Panek AD Trehalose accumulation in mutants of Saccharomyces cerevisiae deleted in the UDPG-dependent trehalose synthase-phosphatase complex. Biochem Biophys Acta. 1997;1335:40-50.

14. Orikasa Y, Mikumo D, Ohwada T. A 2-Deoxyglucose-resistant mutant of Saccharomyces cerevisiae shows enhanced maltose fermentative ability by the activation of MAL genes. Foods. 2018;7:52

15. Sun X, Zhang C-Y, Wu M-Y, Fan Z-H, Liu S-N, Zhu W-B, Xiao D-G. MAL62 overexpression and NTH1 deletion enhance the freezing tolerance and fermentation capacity of the baker's yeast in lean dough. Microb Cell Fact. 2016;15:54

16. Sun X, Zhang J, Fan Z-H, Xiao P, Liu S-N, Li R-P, Zhu W-B, Huang L. MAL62 overexpression enhances freezing tolerance of Baker's yeast in lean dough by enhancing Tps 1 activity and maltose metabolism. J Agric Food Chem. 2019:67:8986-93.

17. Panadero J, Randez-Gil F, Prieto JA. Validation of a flour-free model dough system for throughput studies of baker's yeast. Appl Environ Microbiol. 2005b;71:1142-7.n

18. Inada M, Pleiss JA. Genome-wide approaches to monitor pre-mRNA splicing. Methods Enzymol. 2010;470:51-75.n

19. Young MD, Wakefield MJ, Smyth GK, Oshlack A. Gene ontology analysis for RNA-seq: Accounting for selection bias. Genome Biol. 2010;11:R14.

20. Teste MA, Duquenne M, Francois JM, Parrou JL. Validation of reference genes for quantitative expression analysis by real-time RT-PCR in Saccharomyces cerevisiae. BMC Mol Biol. 2009:10:99.

21. Hottiger T, Schmutz P, Wiemken A. Heat-induced accumulation and futile cycling of trehalose in Saccharomyces cerevisiae. J Bacteriol. $1987 \cdot 169 \cdot 5518-22$
22. Salema-Oom M, de Sousa HR, Assuncao M, Goncalves P, SpencerMartins I. Derepression of a baker's yeast strain for maltose utilization is associated with severe deregulation of HXT gene expression. J Appl Microbiol. 2011;110:364-74.

23. Houghton-Larsen J, Brandt A. Fermentation of high concentrations of maltose by Saccharomyces cerevisiae is limited by the COMPASS methylation complex. Appl Environ Microbiol. 2006;72:7176-82.

24. Dipietro DL, Weinhouse S. Hepatic glucokinase in the fed, fasted, and alloxan-diabetic rat. J Biol Chem. 1960;235:2542-5.

25. Sanchez RG, Hahn-Hagerdal B, Gorwa-Grauslund MF. PGM2 overexpression improves anaerobic galactose fermentation in Saccharomyces cerevisiae. Microb Cell Fact. 2010;9:40.

26. Daran JM, Dallies N, Thines-Sempoux D, Paquet V, Francois J. Genetic and biochemical characterization of the UGP1 gene encoding the UDP-glucose pyrophosphorylase from Saccharomyces cerevisiae. Eur J Biochem. 1995:233:520-30.

27. Blomberg A, Adler L. Roles of glycerol and glycerol-3-phosphate dehydrogenase (NAD+) in acquired osmotolerance of Saccharomyces cerevisiae. J Bacteriol. 1989;171:1087-92.

28. Stewart PR. Analytical methods for yeasts. Methods Cell Biol. 1975;12:111.

29. Spiro RG. Methods in enzymology: complex carbohydrates, vol. 8 || [1] Analysis of sugars found in glycoproteins. 1966. p. 3-26.

30. Klein CJ, Olsson L, Ronnow B, Mikkelsen JD, Nielsen J. Alleviation of glucose repression of maltose metabolism by MIG1 disruption in Saccharomyces cerevisiae. Appl Environ Microbiol. 1996;62:4441-9.

31. Gueldener U, Heinisch J, Koehler GJ, Voss D, Hegemann JH. A second set of loxP marker cassettes for Cre-mediated multiple gene knockouts in budding yeast. Nucleic Acids Res. 2002;30:e23.

32. Sanchez-Fresneda R, Guirao-Abad JP, Arguelles A, Gonzalez-Parraga P, Valentin E, Arguelles JC. Specific stress-induced storage of trehalose, glycerol and D-arabitol in response to oxidative and osmotic stress in Candida albicans. Biochem Biophys Res Commun. 2013;430:1334-9.

33. Hohmann S, Winderickx J, de Winde JH, Valckx D, Cobbaert P, Luyten K, de Meirsman C, Ramos J, Thevelein JM. Novel alleles of yeast hexokinase PII with distinct effects on catalytic activity and catabolite repression of SUC2. Microbiology. 1999;145:703-14.

34. Gustin MC, Albertyn J, Alexander M, Davenport K. MAP kinase pathways in the yeast Saccharomyces cerevisiae. Microbiol Mol Biol Rev. 1998:62:1264-300.

35. Hohmann S. Osmotic stress signaling and osmoadaptation in yeasts. Microbiol Mol Biol Rev. 2002:66:300-72.

36. Hayashi M, Maeda T. Activation of the HOG pathway upon cold stress in Saccharomyces cerevisiae. J Biochem. 2006;139:797-803.

37. Hohmann S. Control of high osmolarity signalling in the yeast Saccharomyces cerevisiae. FEBS Lett. 2009;583:4025-9.

38. Shi X, Miao Y, Chen JY, Chen J, Li W, He X, Wang J. The relationship of freeze tolerance with intracellular compounds in Baker's yeasts. Appl Biochem Biotechnol. 2014;172:3042-53.

39. Hernandez-Lopez MJ, Prieto JA, Randez-Gil F. Osmotolerance and leavening ability in sweet and frozen sweet dough Comparative analysis between Torulaspora delbrueckii and Saccharomyces cerevisiae baker's yeast strains. Anton Van Leeuwenhoek Int J Gen Mol Microbiol. 2003;84:125-34.

40. Trevisol ETV, Panek AD, De Mesquita JF, Eleutherio ECA. Regulation of the yeast trehalose-synthase complex by cyclic AMP-dependent phosphorylation. Biochim Biophys Acta Gen Subjects. 2014;1840:1646-50.

41. Mahmud SA, Hirasawa T, Shimizu H. Differential importance of trehalose accumulation in Saccharomyces cerevisiae in response to various environmental stresses. J Biosci Bioeng. 2010;109:262-6.

42. Kandror O, Bretschneider N, Kreydin E, Cavalieri D, Goldberg AL. Yeast adapt to near-freezing temperatures by STRE/Msn2,4-dependent induction of trehalose synthesis and certain molecular chaperones. Mol Cell. 2004:13:771-81.

43. Dietvorst J, Brandt A. Flocculation in Saccharomyces cerevisiae is repressed by the COMPASS methylation complex during high-gravity fermentation. Yeast. 2008;25:891-901.

44. Charron MJ, Read E, Haut SR, Michels CA. Molecular evolution of the telomere-associated MAL loci of Saccharomyces. Genetics. 1989;122:307-16. 
45. Ruijter GJG, Visser J, Rinzema A. Polyol accumulation by Aspergillus oryzae at low water activity in solid-state fermentation. Microbiology. 2004;150:1095-101.

46. Sleator RD, Hill C. Compatible solutes: the key to Listeria's success as a versatile gastrointestinal pathogen? Gut Pathog. 2010;2:20.

47. Naghshbandi MP, Tabatabaei M, Aghbashlo M, Gupta VK, Sulaiman A, Karimi K, Moghimi H, Maleki M. Progress toward improving ethanol production through decreased glycerol generation in Saccharomyces cerevisiae by metabolic and genetic engineering approaches. Renew Sustain Energy Rev. 2019;115:109353.

48. Semkiv MV, Ruchala J, Dmytruk KV, Sibirny AA. 100 years later, what is new in glycerol bioproduction? Trends Biotechnol. 2020;38:907-16.

49. Albertyn J, Hohmann S, Thevelein JM, Prior BA. GPD1, which encodes glycerol-3-phosphate dehydrogenase, is essential for growth under osmotic stress in Saccharomyces cerevisiae, and its expression is regulated by the high-osmolarity glycerol response pathway. Mol Cell Biol. 1994;14:4135-44.

50. Hirayama T, Maeda T, Saito H, Shinozaki K. Cloning and characterization of seven cDNAs for hyperosmolarity-responsive (HOR) genes of Saccharomyces cerevisiae. Mol Gen Genet. 1995;249:127-38.

51. Remize F, Cambon B, Barnavon L, Dequin S. Glycerol formation during wine fermentation is mainly linked to Gpd1p and is only partially controlled by the HOG pathway. Yeast. 2003;20:1243-53.

52. WinderickX J, de Winde JH, Crauwels M, Hino A, Hohmann S, Van Dijck P, Thevelein JM. Regulation of genes encoding subunits of the trehalose synthase complex in Saccharomyces cerevisiae: novel variations of STREmediated transcription control? Mol Gen Genet. 1996;252:470-82

53. Mizushima D, Iwata H, Ishimaki Y, Ogihara J, Kato J, Kasumi T. Two glycerol 3-phosphate dehydrogenase isogenes from Candida versatilis SN-18 play an important role in glycerol biosynthesis under osmotic stress. J Biosci Bioeng. 2016;121:523-9.

54. Martinez-Pastor MT, Marchler G, Schuller C, Marchler-Bauer A, Ruis H, Estruch F. The Saccharomyces cerevisiae zinc finger proteins Msn2p and Msn4p are required for transcriptional induction through the stress response element (STRE). EMBO J. 1996;15:2227-35.

55. de Nadal E, Alepuz PM, Posas F. Dealing with osmostress through MAP kinase activation. EMBO Rep. 2002;3:735-40.

56. de Arruda Moura Pietrowski G, Grochoski M, Sartori GF, Gomes TA, Wosiacki G, Nogueira A. Viability of Hanseniaspora uvarum yeast preserved by lyophilization and cryopreservation. Yeast. 2015;32:559-65.

57. Aslankoohi E, Rezaei MN, Vervoort Y, Courtin CM, Verstrepen KJ. Glycerol production by fermenting yeast cells is essential for optimal bread dough fermentation. PLoS ONE. 2015;10:e0119364.

58. Lilly M, Lambrechts MG, Pretorius IS. Effect of increased yeast alcohol acetyltransferase activity on flavor profiles of wine and distillates. Appl Environ Microbiol. 2000;66:744-53.nn

59. Cui DY, Zhang Y, Xu J, Zhang CY, Li W, Xiao DG. PGK1 promoter library for the regulation of acetate ester production in Saccharomyces cerevisiae during Chinese Baijiu fermentation. J Agric Food Chem. 2018;66:7417-27. $\mathrm{nn}$

\section{Publisher's Note}

Springer Nature remains neutral with regard to jurisdictional claims in published maps and institutional affiliations.
Ready to submit your research? Choose BMC and benefit from:

- fast, convenient online submission

- thorough peer review by experienced researchers in your field

- rapid publication on acceptance

- support for research data, including large and complex data types

- gold Open Access which fosters wider collaboration and increased citations

- maximum visibility for your research: over $100 \mathrm{M}$ website views per year

At BMC, research is always in progress.

Learn more biomedcentral.com/submissions 